
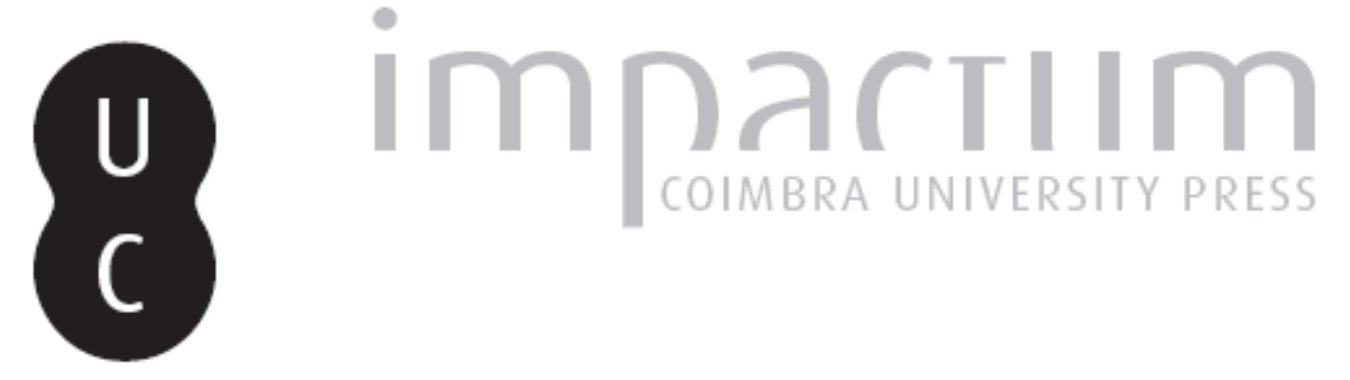

\title{
A inércia institucional nos processos de integração regional: o método do Path Dependence aplicado aos casos da União Europeia e do Mercosul
}
Autor(es):
Szucko, Angélica Saraiva
Publicado por:
Centro de Estudos Interdisciplinares do Século XX; Centro de
Informação Europe Direct de Aveiro; Imprensa da Universidade de Coimbra
URL persistente:
URI:http://hdl.handle.net/10316.2/41328
DOI: ～DOI:https://doi.org/10.14195/1647-6336_16_2

Accessed : $\quad$ 26-Apr-2023 12:55:46

A navegação consulta e descarregamento dos títulos inseridos nas Bibliotecas Digitais UC Digitalis, UC Pombalina e UC Impactum, pressupõem a aceitação plena e sem reservas dos Termos e Condições de Uso destas Bibliotecas Digitais, disponíveis em https://digitalis.uc.pt/pt-pt/termos.

Conforme exposto nos referidos Termos e Condições de Uso, o descarregamento de títulos de acesso restrito requer uma licença válida de autorização devendo o utilizador aceder ao(s) documento(s) a partir de um endereço de IP da instituição detentora da supramencionada licença.

Ao utilizador é apenas permitido o descarregamento para uso pessoal, pelo que o emprego do(s) título(s) descarregado(s) para outro fim, designadamente comercial, carece de autorização do respetivo autor ou editor da obra.

Na medida em que todas as obras da UC Digitalis se encontram protegidas pelo Código do Direito de Autor e Direitos Conexos e demais legislação aplicável, toda a cópia, parcial ou total, deste documento, nos casos em que é legalmente admitida, deverá conter ou fazer-se acompanhar por este aviso.
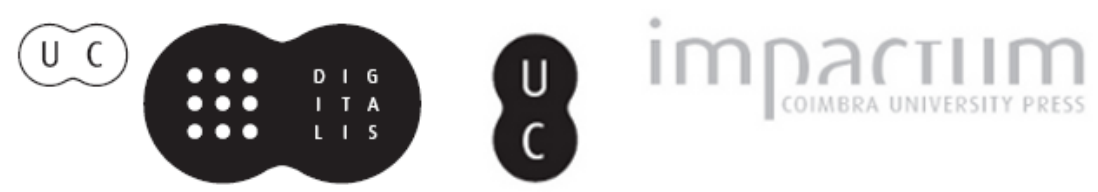
DEBATER

A EUROPA

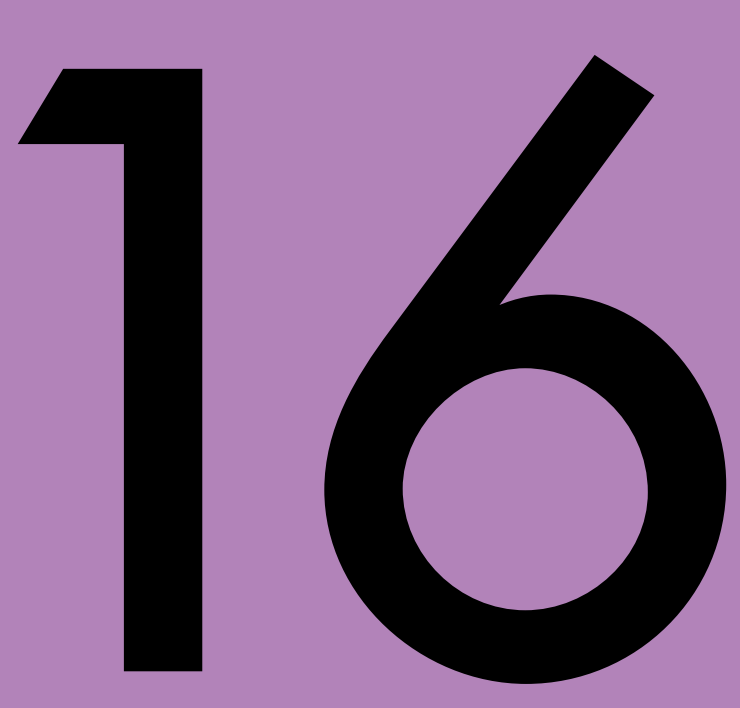

jan-jun 2017

FENÓMENOS DE INTEGRAÇÃO

REGIONAL: OS CASOS DA UNIĨO

EUROPEIA E O MERCOSUL

PHENOMENA OF REGIONAL INTEGRATION: THE

CASES OF THE EUROPEAN UNION AND MERCOSUR 


\title{
A inércia institucional nos processos de integração regional - o método do Path Dependence aplicado aos casos da União Europeia e do Mercosul
}

\author{
The institutional inertia in regional integration processes - the \\ path dependence method applied to the cases \\ of the European Union and Mercosur
}

Angélica Saraiva Szucko Mestranda em Relações Internacionais, UnB, Brasil

E-mail: angelicaszucko@gmail.com

\section{Resumo}

Este artigo tem o objetivo de demonstrar, por meio do método histórico do path dependence, o desenrolar dos processos de integração da União Europeia e do Mercosul e a consequente inércia institucional dos mesmos, bem como comparar suas dificuldades e seus avanços. Primeiramente, será apresentado um breve panorama das teorias de integração regional. Posteriormente, mediante uma análise histórico-comparativa de path dependence, serão identificadas as conjunturas críticas, o processo de reprodução institucional e as sequências reativas de cada um dos casos. Em seguida, será avaliada a inércia institucional resultante desses processos de integração.

Palavras-chave: integração regional; União Europeia; Mercosul; path dependence; inércia institucional

\section{Abstract}

This article aims to demonstrate, through the historical method of path dependence, the development of integration processes of the European Union and MERCOSUR and their consequent institutional inertia as well as to compare their difficulties and advances. Firstly, a brief overview of the theories of regional integration will be presented. Secondly, using a historical-comparative analysis of path dependence, the critical junctures, the institutional reproduction process and the reactive sequences of each case will be identified. Finally, the resulting institutional inertia of these integration processes will be evaluated.

Keywords: regional integration; European Union; MERCOSUR; path dependence; institutional inertia 


\section{Introdução}

A emergência de uma ordem mundial cada vez mais globalizada e interconectada bem como a dificuldade de os Estados se adaptarem a esse sistema e lidarem com as novas temáticas internacionais de forma individual evidenciam a importância da formação de grupos ou blocos que cooperem na busca de um objetivo comum. Nesse sentido, a integração regional é um importante instrumento na elaboração de estratégias associadas para enfrentar problemas que transcendem as fronteiras estatais. Os estudos acerca da integração procuram compreender quais fatores contribuem para que os países busquem soluções coletivas ao invés de agirem individualmente.

As experiências europeia e mercosulina são largamente apontadas como aquelas que mais avançaram em termos de estratégias de atuação coletiva e, por esta razão, servem de referência para grande parte dos estudos sobre cooperação e integração regional. Diferentemente de outros blocos regionais, o processo europeu vai além da cooperação econômica e comercial e consiste em uma integração muito mais ampla e abrangente, aproximando-se mais de um estágio de união política intergovernamental do que da definição corrente de bloco econômico. Embora a Europa seja um continente historicamente marcado por guerras e por inúmeras controvérsias e caracterizado por enorme diversidade cultural, a unificação europeia sugere-nos que é possível cooperar em torno de um objetivo e de um compromisso comuns. A integração europeia está fundada tanto em um processo de consolidação institucional como na formação de uma comunidade supranacional com valores compartilhados. São esses motivos que a diferenciam dos demais processos de integração regional e que despertam crescente interesse por suas singularidades e pelos avanços na cooperação interestatal.

O Mercosul, por sua vez, é considerado uma união aduaneira imperfeita, em função das exceções ainda existentes, com matizes de mercado comum, a exemplo dos avanços na área de circulação de pessoas com a isenção de vistos e os acordos de residência. Esse bloco também avançou em outras áreas de cooperação interestatal que não somente a redução de barreiras tarifárias, a exemplo do adensamento político por meio das Cúpulas Presidenciais e da criação do Parlamento do Mercosul (Parlasul) e do cargo de Alto Representante Geral, e dos avanços na área social, como o Mercosul Social e Participativo, entre outras ações.

Este artigo tem o objetivo de demonstrar, por meio do método histórico do path dependence, o início do desenrolar dos processos de integração da União Europeia e do Mercosul e a consequente inércia institucional dos mesmos, bem como comparar suas dificuldades e avanços. Segundo James Mahoney (2001, pg. 111), "path dependence occurs when the choices of key actors at critical juncture points lead to the formation of institutions that have self-reproducing properties". No caso dos processos de integração regional, estabelece-se um ponto de inflexão no relacionamento entre os países-membros a partir do qual se constrói uma estrutura institucional que determina as 
novas possibilidades de escolhas futuras. Sendo assim, uma vez escolhido um caminho em um momento crítico, fica mais difícil voltar atrás. Essa hipótese pode explicar, em alguma medida, o motivo pelo qual ambos os processos de integração nunca tiveram grandes retrocessos ainda que em determinadas áreas, como segurança e defesa, permaneçam sem avanços significativos.

O estudo será dividido em três partes. Primeiramente, será apresentado um breve panorama das principais teorias de integração regional. Posteriormente, mediante uma análise histórico-comparativa de path dependence, serão identificadas as condições antecedentes, as conjunturas críticas, os processos de reprodução institucional e as sequências reativas de cada um dos casos, dando destaque aos eixos franco-alemão, na União Europeia, e argentino-brasileiro, no Mercosul. Em seguida, será avaliada a inércia institucional resultante desses processos, com o aumento da burocratização e a dificuldade em realizar reformas profundas. Serão pontuados, ainda, os atuais desafios destes dois blocos regionais. De modo geral, o artigo propõe-se a analisar os casos europeu e mercosulino, tendo por base a metodologia histórico-comparativa e o path dependence, com o intuito de compreender melhor os desdobramentos institucionais desses processos de integração.

\section{As teorias de integração regional}

A temática da integração regional está presente em uma vasta literatura, e diferentes abordagens teóricas possuem conceitos úteis que nos ajudam a compreender melhor sua construção. A integração regional é entendida como o "processo dinâmico de intensificação em profundidade e abrangência das relações entre atores levando à criação de formas de governança político-institucionais de escopo regional" (HERZ; HOFFMANN, 2004, pg. 168 apud COUTINHO; HOFFMANN; KFURI, 2007, pg.7). O processo de integração regional, por sua vez, pode ser desmembrado, ainda, em diferentes dimensões - a saber, a econômica, a político-institucional e a social -, que muitas vezes progridem em ritmos diferentes. Essa desagregação nos auxilia a compreender melhor o processo como um todo e a verificar quais os graus de profundidade e de abrangência da integração.

A ideia de integração regional nos termos que conhecemos hoje surgiu com a criação da Comunidade Europeia do Carvão e do Aço (CECA), em 1951, e com seus posteriores desdobramentos na formação da Comunidade Econômica Europeia (CEE) e da Comunidade Europeia de Energia Atômica (Euratom), por meio dos Tratados de Roma, em 1957. Desde então, procurou-se analisar quais os fatores contribuiriam para esse processo de integração regional e de cooperação interestatal.

Num primeiro momento, o motivo principal vinculava-se ao objetivo de evitar novos conflitos no continente europeu, especialmente entre França e Alemanha, e, posteriormente, estendeu-se a razões econômicas e políticas que justificavam a aproximação e a cooperação entre os Estados dentro de um sistema de interdependência complexa. Na América Latina, 
a Associação Latino-Americana de Livre Comércio (ALALC), criada em 1960, representou uma tentativa nesse sentido da integração regional e foi substituída pela Associação Latino-Americana de Integração (ALADI), em 1980.

As explicações teóricas para esses fenômenos integracionistas são diversas e agregam elementos econômicos e políticos. De modo geral, estas teorias foram desenvolvendo-se paralelamente ao processo de integração europeu e com o intuito de explicar seus desdobramentos; no entanto, não necessariamente se sucedem no tempo: algumas perspectivas continuam existindo e se desenvolvendo mesmo após o surgimento das demais. Em síntese, as principais teorias explicativas da integração regional são o federalismo, o funcionalismo, o neofuncionalismo, o neoinstitucionalismo e o intergovernamentalismo (PINTO, 2004).

O federalismo preconiza a transferência voluntária de parte da soberania estatal para as instituições supranacionais regionais, as quais seriam responsáveis pela definição das políticas comuns, em um modelo similar ao de Estados federativos. De acordo com Sabine Saurugger (2009, p. 134-135), o federalismo corresponde a "un mode de gouvernement qui repose sur une convention (foedus) entre communautés politiques indépendantes et, surtout, égales pour agir ensemble tout en demeurant séparées "'. Em geral, o federalismo fica à margem das teorias utilizadas para estudar os processos de integração dado seu caráter altamente normativo, em função da proposta de formação de uma federação de Estados, e o fato de que é uma abordagem que não traz hipóteses para validar como e por que motivo o processo de integração se constrói, mas, sim, um modelo de integração a ser implementado.

Com o fim da Segunda Guerra Mundial, o federalismo e o funcionalismo surgiram como alternativas para a construção de relações pacíficas na Europa. Enquanto o federalismo entendia que iniciativas políticas para a construção de estruturas federais supranacionais, na forma de uma união federal entre os Estados europeus, eram o caminho para paz europeia, o funcionalismo afirmava que a cooperação interestatal em áreas técnicas e funcionais específicas, por meio de organizações internacionais, conduziria a um sistema mais próspero e pacífico.

A teoria funcionalista considera que a integração regional é alcançada mediante a cooperação interestatal em tarefas funcionais, principalmente de natureza técnica e econômica. Desta forma, haveria uma transferência da soberania, em áreas específicas, para as instituições regionais, que seriam dirigidas por elites técnicas. Para David Mitrany (1990), principal teórico do funcionalismo, o contexto que favorece a integração regional é a existência de problemas técnicos que não podem ser resolvidos apenas nacionalmente e demandam a cooperação com outros Estados da região que têm as mesmas necessidades, dando origem, então, a organizações internacionais. Essa cooperação ocorre inicialmente entre as burocracias similares dos Estados, ainda que não em nível estatal, e se prolifera para outros campos. Sendo assim, uma vez que a colaboração funcional em um determinado setor gere efeitos

\footnotetext{
1 "uma forma de governo baseada em um acordo (foedus) entre comunidades políticas independentes e, sobretudo, iguais para agir em conjunto ainda que se mantenham separadas”. (Tradução nossa)
} 
positivos, pode-se resultar cooperação também em outras áreas, a chamada Doutrina da Ramificação de David Mitrany.

Ao final da década de 1950 e início dos anos 1960, o neofuncionalismo surge como uma perspectiva teórica que busca explicar os avanços da integração europeia, anteriormente setorial com a CECA e que gerou os spillovers necessários à criação da CEE. O neofuncionalismo deriva da lógica funcionalista; no entanto, além dos aspectos técnicos, questões políticas e econômicas também podem desencadear o processo de integração. Ernest Haas, teórico do neofuncionalismo, destaca a importância dos papéis dos grupos de interesse e dos partidos políticos que, ao promoverem seus interesses, induzem o processo de integração. Sendo assim, existem quatro motivações principais para integração: a promoção da segurança comum, a obtenção do desenvolvimento econômico e do bem-estar social, o interesse de uma nação mais forte de controlar os seus aliados menores e a vontade comum de unificar as sociedades (HAAS, 1956 apud MARIANO; MARIANO, 2002). Segundo Haas:

(...) a integração regional é um processo pelo qual os atores políticos de diferentes comunidades nacionais são levados a reorientar as suas lealdades, as suas aspirações e as suas atividades políticas para um novo centro, cujas instituições possuem, ou procuram possuir, competências que sobrepõem às dos Estados nacionais pré-existentes. (HAAS apud PINTO, 2004).

De acordo com a teoria neofuncionalista, a integração seria impulsionada por um núcleo central constituído pelos governos e pelas burocracias especializadas a partir do qual se iria esparramando, em um efeito de spillover, para a sociedade, criando novas dinâmicas de interação. O conceito de spillover, isto é, o aumento nos níveis de interdependência que conduz a um processo de cooperação e de integração política, é central para os neofuncionalistas. Segundo Karina L. P. Mariano e Marcelo P. Mariano (2002, pg. 58), “a conclusão lógica da teoria neofuncionalista sobre o spillover é a necessidade de criação de uma burocracia voltada para administrar as questões referentes à integração, de preferência com caráter supranacional".

Para os teóricos neofuncionalistas, a construção europeia explicava-se pela integração gradual em setores específicos, no caso o econômico, que geraram um efeito de transbordamento (spillover effect) para outras áreas. De fato, o aspecto supranacional esteve presente na construção das instituições europeias, mas este processo foi e ainda é permeado por negociações fundamentadas em barganhas intergovernamentais.

A partir da década de 1970, o neoinstitucionalismo procurou elucidar o papel que as instituições desempenham na determinação dos resultados sociais e políticos. A teoria neoinstitucionalista entende que "a presença de instituições internacionais no sistema político mundial influencia o comportamento dos governos e é central para analisar a cooperação entre Estados" (MARIANO; MARIANO, 2002, pg. 60). As instituições, segundo 
os neoinstitucionalistas, promovem a cooperação e criam incentivos para que os Estados solucionem suas disputas mediante o estabelecimento de regras, de padrões de conduta e de estruturas que guiam o comportamento dos atores. Em outras palavras, as instituições são criadas pelos Estados com o intuito de alcançar objetivos comuns, e essa interação estratégica pode levar à cooperação.

Para Robert Keohane (1989, pg. 3 apud MARIANO; MARIANO, 2002, pg. 60), as instituições são "um conjunto de regras permanentes e conectadas (formal ou informal) que definem os papéis comportamentais, limitam a ação e compartilham expectativas". A abordagem neoinstitucionalista entende que as instituições exercem um papel importante para superar as falhas de mercado, resolver as dificuldades de coordenação e reduzir os obstáculos e os riscos à cooperação econômica, ao aumentar os canais de comunicação entre os Estados. Entretanto, mesmo que o neoinstitucionalismo tenha auxiliado no desenvolvimento do pensamento sobre instituições regionais, não foi capaz de criar uma teoria especifica para explicar a integração (PINTO, 2004).

Entre os anos 1960 e 1970, a teoria intergovernamentalista apresentava grande potencial explicativo para os acontecimentos no seio da integração europeia, a exemplo da crise da cadeira vazia de De Gaulle ${ }^{2}$ e o veto à entrada britânica ${ }^{3}$, das dificuldades na integração econômica e do reforço do aspecto intergovernamental na sequência do primeiro alargamento do bloco, em 1973. O intergovernamentalismo destaca os interesses econômicos como principal força condutora da integração regional e atribui papel fulcral aos governos nacionais dentro das instituições regionais. Os intergovernamentalistas destacam a centralidade do Estado no processo de integração regional e interpretam a cooperação interestatal como derivada das decisões racionais de cada país com vistas a atender seus interesses nacionais. Em outras palavras, os Estados só cooperam quando isso satisfaz seus interesses individuais.

A teoria intergovernamentalista entende que os Estados são atores racionais e que seus comportamentos refletem as pressões tanto internas, de vários grupos da sociedade, quanto externas, oriundas do próprio ambiente internacional (MARIANO; MARIANO, 2002). Para os intergovernamentalistas, a integração regional segue dois estágios. Primeiramente, os governos definem internamente seus interesses nacionais que conduzirão suas ações no plano internacional. Posteriormente, no processo de negociação interestatal, inicia-se uma série de barganhas. Desta forma, o intergovernamentalismo caracteriza-se

\footnotetext{
${ }^{2}$ Opondo-se a reformas (passagem do voto por unanimidade para o voto por maioria qualificada no Conselho da União Europeia; e mudanças nas modalidades de financiamento do Fundo Europeu de Orientação e Garantia Agrícola), a França paralisou o processo decisório do Conselho da União Europeia em 1965, ao convocar seu representante permanente em Bruxelas e recusar-se a participar de reuniões no Conselho por cerca de seis meses. Pelo Compromisso de Luxemburgo, de 1966, a unanimidade foi mantida como critério decisório em questões de grande importância para um ou mais países membros.

${ }^{3}$ O primeiro veto do presidente francês Charles De Gaulle ocorreu em janeiro de 1963, pois temia a vinculação do Reino Unido com os EUA naquele momento da Guerra Fria. Em 1967, o Presidente francês vetou a entrada britânica na Comunidade Econômica Europeia pela segunda vez, sob o argumento de que o nível de integração era incompatível com a economia do Reino Unido.
} 
pela análise em jogos de dois níveis: no nível interno, investiga a formação das preferências nacionais dos Estados; no externo, examina o processo de barganhas intergovernamentais e foca na coordenação política entre os Estados no processo de integração.

As instituições internacionais, por sua vez, possibilitam maior eficiência tanto na barganha como na coordenação interestatal e, nesse sentido, fortalecem os governos nacionais. Ademais, frente à inerente interdependência internacional, cooperar torna-se mais vantajoso. O intergovernamentalismo, assim como o neoinstitucionalismo, não é uma teoria específica de integração regional, mas, sim, um modelo teórico de relações internacionais que pode ser aplicado aos casos de integração regional, pois se fundamenta em suposições sobre o papel do Estado em um ambiente de cooperação interestatal (MARIANO; MARIANO, 2002).

Esses modelos teóricos nos auxiliam a entender a ação dos Estados dentro de um sistema internacional interdependente e complexo. A cooperação interestatal e a integração surgem como formas de superar os atritos regionais e de promover interesses comuns. No caso da União Europeia e do Mercosul, a aproximação, respectivamente, dos eixos franco-alemão e argentino brasileiro e a mudança em seus padrões de interação e relacionamento resultou na consolidação dos blocos regionais. De acordo com Karina L. P. Mariano e Marcelo P. Mariano:

Os governos são constantemente coagidos a encontrar soluções para problemas e impactos negativos decorrentes da integração. Ao mesmo tempo, suas ações devem estar coordenadas com os demais países para evitar desentendimentos prejudiciais ao avanço e aprofundamento do processo. $\mathrm{O}$ aprofundamento do processo de integração cria novas demandas de coordenação política entre os países envolvidos, como consequência da maior interação (MARIANO; MARIANO, 2002, pg.62).

Esse fato pode ser verificado tanto na União Europeia como no Mercosul, cujas agendas de negociações gradativamente foram ampliadas, conforme o processo avançou. Embora, como ressaltado anteriormente, estes exemplos sejam muito mais do que apenas blocos econômicos, é interessante analisar este aspecto da integração que evidencia a ampliação da agenda de cooperação interestatal.. No que se refere às teorias de integração econômica, os estudos sistematizaram-se após o final da Segunda Guerra Mundial, quando se reconheceu o insucesso do isolacionismo, tanto no plano econômico como no político, e a necessidade de caminhar para um comércio mais livre por meio de instituições internacionais.

Segundo a classificação clássica do economista húngaro Béla Balassa, pode-se dividir esse processo, basicamente, em seis etapas, de acordo com a diminuição das barreiras comerciais entre os participantes, a saber: 1) sistema de preferências aduaneiras, com a redução de algumas barreiras tarifárias; 2) área de livre comércio, com a eliminação das 
tarifas alfandegárias entre os países-membros; 3) união aduaneira, com o estabelecimento de uma tarifa externa comum; 4) mercado comum, com a livre circulação de bens, capital, trabalho e serviços; 5) união econômica e monetária, com a introdução de uma moeda única e uma política monetária comum; 6) integração econômica total, com políticas econômicas e fiscais harmonizadas (EUROPEAN COMMISSION, 2015, p.1).

Em um sistema de preferências aduaneiras, apenas algumas restrições tarifárias são removidas, de maneira a facilitar o comércio, como exemplificam as Convenções de Lomé entre a União Europeia e os países da África, Caribe e Pacífico (ACP), especialmente as ex-colônias europeias. A área de livre comércio, por sua vez, caracteriza-se pela livre movimentação de produtos oriundos dos países-membros, ainda que estes mantenham suas políticas comerciais próprias em relação a terceiros, como é o caso do North American Free Trade Agreement (NAFTA). Na união aduaneira, além da livre circulação de mercadorias, estabelece-se uma política comercial comum, mediante a aplicação de uma tarifa externa comum. Ademais, os países-membros podem assumir o compromisso de negociação conjunta de acordos comerciais com países terceiros, como ocorre entre a União Europeia e o Mercosul. O mercado comum, por sua vez, caracteriza-se pela livre circulação de bens, de pessoas, de serviços e de capitais, com a eliminação de barreiras tarifárias e não tarifárias que poderiam impedir a concorrência plena entre as economias dos países-membros. A união econômica prevê a harmonização das legislações econômicas nacionais, bem como a coordenação de políticas econômicas no plano regional. Já a união monetária pressupõe a existência de uma política monetária comum e uma moeda única, como o é o caso da Zona Euro. Por fim, a integração econômica total dar-se-ia com a harmonização também das políticas fiscais.

Atualmente, a União Europeia é o exemplo mais avançado no que se refere à integração econômica e se encontra entre os estágios quatro e cinco, visto que nem todos os países do bloco fazem parte da Zona Euro ${ }^{4}$ e que não há harmonização das políticas fiscais. O Mercosul, a seu turno, possui características dos estágios dois, três e quatro ao mesmo tempo. As peculiaridades do Mercosul derivam do fato de que os setores automotivo e açucareiro estão excluídos do livre comércio no âmbito, assim como há listas de exceção à tarifa externa comum (TEC), característica de uma união aduaneira. Ademais, o bloco sul-americano apresenta alguns atributos de mercado comum, como a livre circulação de pessoas sem a necessidade de apresentação de passaporte e a eliminação progressiva de entraves à circulação dos fatores de produção.

Vale ressaltar que uma vez iniciado o processo de integração econômica, é razoavelmente improvável que se regrida ao estágio anterior. Isto porque, para que a integração

\footnotetext{
${ }^{4}$ Atualmente, 19 dos 28 Estados membros da União Europeia fazem parte da Zona Euro. À exceção do Reino Unido e da Dinamarca, que acordaram uma opção de exclusão no Tratado de Maastricht, todos os demais Estados membros da União Europeia são legalmente obrigados a aderir à moeda comum assim que sejam atendidos os critérios de convergência.
} 
se efetivasse, foram criadas diversas instituições, regras e mecanismos de convergência e de regulação, e, em certa medida, a inércia e a persistência institucional torna muito mais difícil retroceder à um ponto inicial do que estagnar ou do que aprofundar o processo.

\section{O método do Path Dependence aplicado aos casos da União Europeia e do Mercosul}

O método do path dependence corresponde a uma explicação fundamentada em uma série de estágios sequenciais. Nesse sentido, o ponto inicial é formulado a partir dos antecedentes históricos que definem as opções disponíveis para os atores em um momento-chave. Neste momento-chave ou conjuntura crítica, uma determinada opção é escolhida entre as alternativas existentes, a qual conduz a criação de padrões institucionais que perduram no tempo. A persistência institucional, por sua vez, desencadeia uma sequência reativa na qual os atores respondem ao sistema vigente e aos padrões de comportamento estruturados por este. Essas reações podem conduzir ao desenvolvimento de um resultado final que represente a resolução dos conflitos que marcaram essas sequências reativas (MAHONEY, 2001). A figura abaixo sintetiza a estrutura analítica da explicação do path dependence.

Figura 1: Analytic Structure of Path-Dependent Explanation

\begin{tabular}{|c|c|c|c|c|}
\hline $\begin{array}{l}\text { Antecedent } \\
\text { Conditions }\end{array}$ & $\begin{array}{l}\text { Critical } \\
\text { juncture }\end{array}$ & $\begin{array}{l}\text { Structural } \\
\text { persistence }\end{array}$ & $\begin{array}{l}\text { Reactive } \\
\text { sequence }\end{array}$ & Outcome \\
\hline $\begin{array}{l}\text { Historical factors } \\
\text { that define } \\
\text { available options } \\
\text { and shape } \\
\text { selection } \\
\text { processes }\end{array}$ & $\begin{array}{l}\text { Selection of a } \\
\text { particular option } \\
\text { (e.g. policy } \\
\text { option) from } \\
\text { among multiple } \\
\text { alternatives }\end{array}$ & $\begin{array}{l}\text { Production } \\
\quad \text { and } \\
\text { reproduction } \\
\text { of institution } \\
\text { or structural } \\
\text { pattern }\end{array}$ & $\begin{array}{l}\text { Reactions and } \\
\text { counterreactions } \\
\text { to institution of } \\
\text { structural pattern }\end{array}$ & $\begin{array}{l}\text { Resolution of } \\
\text { conflict } \\
\text { generated by } \\
\text { reactions and } \\
\text { counterreactions }\end{array}$ \\
\hline
\end{tabular}

Fonte: MAHONEY, 2001, pg.113

As condições antecedentes representam a referência básica sobre a qual a conjuntura crítica e seu legado são avaliados; isto é, auxiliam-nos a analisar se a rota tomada pelo fenômeno estudado foi realmente alterada a partir do momento critico ou se permaneceu vinculada às condições anteriores. Ademais, são as condições antecedentes que definem as opções disponíveis para escolha a ser realizada na conjuntura crítica (FERNANDES, 2002).

Em relação às conjunturas críticas, existem dois componentes que amparam sua definição. Primeiramente, são pontos de escolha nos quais uma opção em particular é adotada dentre algumas alternativas. E, em segundo lugar, uma vez escolhida uma determinada opção, torna-se progressivamente mais difícil retornar ao ponto inicial no qual diversas 
alternativas ainda estavam disponíveis (MAHONEY, 2001). Mahoney (2001, pg.113) esclarece: "only those choice points that close off important future outcomes should be treated as critical junctures". Por esta razão, é importante atentar para a escolha de quais momentos realmente representam conjunturas críticas.

(...) a ideia de escolhas cruciais e seus legados, que pode ser chamada de momentos críticos, tem como foco principal circunstâncias decisivas na vida política, onde ocorrem transições que estabelecem certas direções e excluem num caminho que molda a política por anos (FERNANDES, 2002,pg. 85).

O método do path dependence auxilia nas explicações históricas dos fenômenos ao determinar um ponto-chave de inflexão que deve ser considerado para o estudo, evitando, assim, a regressão infinita ao passado para explicar certos eventos. Ademais, reitera-se a ideia de que é muito mais oneroso aos atores reverterem a escolha feita durante esse momento crítico. Isto se explica porque as decisões tomadas conduzem a determinados caminhos de desenvolvimento e levam à formação de instituições que tendem a manter-se ao longo dos anos subsequentes e que não podem ser facilmente transformadas (MAHONEY, 2001).

O processo de persistência institucional vincula-se à ideia de "retornos crescentes" da economia, os quais significam que "a probabilidade de dar um passo à frente no mesmo caminho ou trajetória estabelecida aumenta cada vez que se move para dentro do próprio caminho" (FERNANDES, 2002, pg. 83). Em outras palavras, os benefícios relativos de manter-se na mesma trilha aumentam com o tempo, pois optar por outra trajetória, mudando o curso até então seguido, implica custos mais elevados. Desta forma, os atores tendem a reproduzir as instituições em função dos benefícios de aprendizagem e de coordenação, bem como dos custos impostos pelos investimentos irreversíveis.

É importante ressaltar aqui que as instituições por sua vez, devem ser compreendidas, de acordo com o conceito de Douglass North (1991), como invenções humanas que estruturam as interações políticas, econômicas e sociais por meio de restrições formais e informais. Em outras palavras, instituições são mecanismos que regem o funcionamento de uma sociedade, e, desta forma, este estudo não considera como instituições somente organizações físicas, mas também padrões de relacionamento que moldam e limitam os comportamentos dos atores.

À persistência dessas instituições ao longo do tempo desencadeia uma sucessão de eventos que, uma vez iniciados, ocorrem independentemente dos fatores institucionais que os produziram num primeiro momento. Essa cadeia de eventos é denominada sequência reativa. A sequência reativa é marcada por reações e por contrarreações ao padrão institucional estabelecido e pela adaptação e pela transformação deste. Os conflitos da sequência reativa, em geral, conduzem a um resultado final mais estável com a formação de um novo padrão institucional. 
Em síntese, para MAHONEY (2001, pg. 115), "path-dependent approach emphasis how actors choices create institutions at critical moments, how these institutions in turn shape subsequent actor behaviors, and how these actor responses in turn culminate in the development of new institutional patterns". Os estudos que se utilizam do método histórico do path dependence procuram analisar como as decisões de determinados atores, ao longo do tempo, são capazes de criar instituições com legados políticos e econômicos quase irreversíveis.

De acordo com Levi (1997, pg. 28 apud FERNANDES, 2002, pg. 79), path dependence "significa que um país, ao iniciar uma trilha, tem os custos aumentados em revertê-la. Existirão outros pontos de escolha, mas as barreiras de certos arranjos institucionais obstruirão uma reversão fácil da escolha inicial". Sendo assim, nos exemplos da União Europeia e do Mercosul, é possível estabelecer um ponto de inflexão no relacionamento bilateral entre, respectivamente, Franca e Alemanha, por um lado, e Brasil e Argentina, por outro, que altera o padrão de comportamento de rivalidade, até então predominante, e o substitui pela cooperação, criando um ambiente propício ao processo de integração regional.

Desta forma, serão analisadas, por meio do método do path dependence, as relações em eixo que deram origem aos processos de integração na Europa e na América do Sul. De acordo com Raquel Patrício (2006), os Estados que compõem as relações em eixo atuam como forças motrizes em um entendimento bilateral de cooperação que se estende para os países vizinhos, catalisando o processo de integração regional, ou seja, estes Estados acabam por atuarem como o eixo de gravitação regional. As relações em eixo podem ser compreendidas como um novo conceito paradigmático para as relações internacionais e definidas como:

(...) uma relação especial estabelecida entre duas potências que fazem fronteiras vivas e desenvolvem profícua complementaridade econômica, numa primeira fase assentando sobre rivalidades mútuas que evoluem, num segundo momento, para um comportamento cooperativo (PATRÍCIO, 2006, pg.6).

O papel dos líderes estatais é fundamental neste processo, pois cabe, essencialmente, a eles e às demais autoridades nacionais promoverem um imaginário unificador mediante iniciativas políticas, de modo a consolidar uma relativa identificação regional que auxilie na dinâmica da integração. Assim sendo, os interesses anteriormente divergentes, por meio de um movimento centrípeto originado pelas relações em eixo, transformam-se em objetivos comuns.

Segundo Raquel Patrício (2006, pg. 5-6), “as relações franco-alemãs e argentino-brasileiras se afirmam como relações em eixo, essenciais para a criação, condução e consolidação dos processos regionais de integração". Ademais, para a autora, qualquer processo 
de integração regional que pretenda alcançar um nível considerável de aprofundamento econômico-político-institucional deve passar por fases gradativas, das quais as relações em eixo são fundamentais. Caso contrário, limitar-se-ia a uma vertente puramente econômica da integração regional.

\section{O eixo franco-alemão e a integração europeia}

Desde a unificação alemã, em 1870, até o fim da Segunda Guerra Mundial, em 1945, as relações entre França e Alemanha foram tensas e conflituosas. A rivalidade mútua explicava-se, principalmente, em função das disputas territoriais na região da Alsácia-Lorena. Com o fim da guerra e suas terríveis consequências, como a deterioração econômica dos países europeus, emergia um clamor pela pacificação e pelo desenvolvimento do continente.

De acordo com Raquel Patrício (2006), o principal ponto de discórdia entre França e Alemanha no pós-Segunda Guerra era o problema siderúrgico do Sarre e do Ruhr, que ressaltava o medo e a desconfiança entre os Estados. Nesse sentido, controlar a produção franco-alemã do carvão e do aço, por meio de uma instituição supranacional, era necessário para tornar qualquer esforço de guerra materialmente impossível e impraticável, bem como para constituir uma terceira via, visando ao desenvolvimento europeu, dentro da lógica do sistema bipolar que se estruturava no sistema internacional. Os motivos para adesão ao projeto de uma Europa unida incluíam, ainda, o compromisso com valores comuns e com princípios denominados europeus, como a paz, o Estado de direito, a economia de mercado, entre outros, que, ademais, se aliavam aos interesses particulares de cada Estado.

O primeiro-ministro britânico Winston Churchill, em discurso proferido no dia 16 de setembro de 1946, na Universidade de Zurique, já ressaltava a importância do aprofundamento das relações franco-alemãs para a construção de uma Europa pacífica e unida, no que ele denominou "Estados Unidos da Europa".

I am now going to say something that will astonish you. The first step in the re-creation of the European family must be a partnership between France and Germany (...) There can be no revival of Europe without a spiritually great France and a spiritually great Germany. The structure of the United States of Europe will be such as to make the material strength of a single State less important (CHURCHILL, 1946).

Sob um ponto de vista similar, Robert Schuman, então ministro francês de Negócios Exteriores, apresentou, em 09 de maio de 1950, uma proposta para a organização de uma Europa pacificada e unida, que passava pela consolidação de relações amistosas entre França e Alemanha. Segundo Schuman (1950): The coming together of the nations of Europe requires the elimination of the age-old opposition of France and Germany. Any action taken must in the first place concern these two countries. Atualmente, no dia 09 
de maio é comemorado o Dia da Europa, pois a declaração de Robert Schuman marcou o início do que se seria, posteriormente, o contemporâneo processo de integração europeia.

Tanto Robert Schuman quanto Konrad Adenauer, chanceler alemão à época, exerceram papel essencial na reaproximação entre Franca e Alemanha, e, em 1951, foi assinado o Tratado de Paris criando a CECA, que simbolizou o início da parceria entre os dois países em um setor estratégico como o do carvão e do ação. Na sequência dos fenômenos econômicos e políticos que se sucederam, esta parceria ultrapassou o quadro de uma organização setorial e abriu caminho para a criação da Euratom e da CEE. Raquel Patrício (2006, pg.11) destaca que "as relações em eixo franco-alemãs, evoluindo no sentido da cooperação, permitiram, assim, desbloquear o impasse franco-alemão, pondo em movimento uma engrenagem não bi, mas multilateral".

O Tratado da Amizade Franco-Alemã, também conhecido como Tratado de Eliseu, firmado pelo líder francês Charles De Gaulle e pelo chanceler alemão Konrad Adenauer, em 1963, assentou os contornos dessa relação bilateral que almejava a pacificação e concretizou a substituição da rivalidade por um comportamento amplamente cooperativo. $\mathrm{Na}$ sequência, as duplas políticas formadas pelos líderes alemães e franceses, a exemplo de Schmidt-Giscard d`Estaing (1974 - 1981) e Kohl-Mitterrand (1982-1995) aproveitaram as bases lançadas pelo tratado e transformaram as duas nações em precursoras da união no continente, ainda que algumas parcerias não tenham sido tão profícuas, como no caso de Schröder-Chirac (1998-2005).

O Tratado de Eliseu marcou o início de uma caminhada que, mediante avanços e períodos de estagnação, se desdobrou, nas décadas seguintes, na construção europeia sob a liderança do eixo franco-alemão. Na década de 1970, a integração europeia se caracterizou pela busca de legitimidade política e por reformas institucionais, por exemplo, com a adoção de eleições diretas e universais para o Parlamento Europeu, a partir de 1979, bem como pelo primeiro alargamento das comunidades europeias em 1973, com a entrada da Dinamarca, do Reino Unido e da Irlanda (BRUTER, 2005).

Nos anos 1980, novos alargamentos com a entrada da Grécia, em 1981, e de Portugal e Espanha, em 1986, ampliaram ainda mais as Comunidades Europeias, trazendo novos desafios para a integração regional. Em 1985, o francês Jacques Delors assumiu a presidência da Comissão Europeia com o apoio dos líderes francês, François Mitterrand, e alemão, Helmut Kohl, e propôs um novo projeto para a Europa denominado "People's Europe". Durante sua presidência, que durou até 1995, a integração europeia ganhou um novo fôlego com a assinatura do Ato Único Europeu, em 1986, e do Tratado de Maastricht, em 1992. Ademais, ainda em 1985, foi assinado o primeiro Acordo Schengen entre cinco países (Alemanha, Bélgica, França Luxemburgo e Países Baixos) e, em 1990, foi elaborada uma convenção mais desenvolvida sobre o Espaço Schengen, a qual entrou em vigor em 1995, com o intuito de suprimir o controle nas fronteiras entre os Estados membros, facilitando a livre circulação de seus cidadãos. 
Após a assinatura do Tratado de Maastricht, intensificou-se ainda mais o processo de integração com uma abordagem mais específica voltada para o desenvolvimento de um novo projeto de democracia (BRUTER, 2005). As comunidades europeias passaram a ser denominadas União Europeia. O Tratado de Maastricht, também conhecido como Tratado da União Europeia, estabeleceu as bases para a Política Externa e de Segurança Comum (PESC), para a formação de uma União Econômica e Monetária (UEM) e para a criação de uma cidadania europeia. Ademais, em uma reunião do Conselho Europeu em 1993, foram estipuladas as condicionalidades para novas adesões ao bloco: os critérios de Copenhague. São eles: 1) o político, que consiste na existência de instituições estáveis que garantam a democracia, o Estado de direito e os direitos humanos; 2) o econômico, que se relaciona à existência de uma economia de mercado que funcione efetivamente; e 3) o acervo comunitário, que se refere à capacidade de aderir à base comum de direitos e de obrigações que vincula todos os Estados membros da União Europeia. Este último determina que os novos Estados membros devem aderir ao que foi previamente estabelecido pelos demais membros da União Europeia. Em outras palavras, trata-se de um alinhamento legislativo, o qual pode ser dividido em capítulos para cada nova admissão. Esses critérios foram aplicados nos posteriores alargamentos do bloco.

Em 1995, Áustria, Finlândia e Suécia adentraram na União Europeia. Em 1999 foi criada, oficialmente, a Zona Euro; no entanto, apenas em 2002, as notas e as moedas de Euro começaram a circular nos onze países que, até aquele momento, atendiam aos critérios de convergência. O maior alargamento do bloco aconteceu em 2004, com a entrada simultânea de 10 novos países-membros: Chipre, Eslováquia, Eslovênia, Estônia, Hungria, Letônia, Lituânia, Malta, Polônia e República Tcheca. Em 2007, Bulgária e Romênia também passaram a integrar a União Europeia, e, em 2013, ocorreu a última adesão, a da Croácia.

Os Tratados de Amsterdã e de Nice, assinados respectivamente nos anos de 1997 e 2001, procuraram promover reformas institucionais que preparassem o bloco para as novas adesões. O Tratado de Lisboa, assinado em 2007, tem o intuito de tornar a União Europeia uma instituição mais democrática, eficaz e apta a responder às demandas no âmbito internacional em uma só voz. Este tratado esclareceu a repartição das competências entre as da União Europeia, as dos países-membros e as compartilhadas; e reforçou os poderes do Parlamento Europeu.

Em todos esses períodos sucessivos da longa integração europeia, o eixo franco-alemão exerceu a função de condutor do processo, o que permitiu superar as dificuldades enfrentadas, como o fracasso da Comunidade Europeia de Defesa, a crise da cadeira vazia e as constantes ondas de euroceticismo. Atualmente, obviamente, as dinâmicas são distintas, visto que a França, apesar de suas grandes ambições políticas, não possui pujança econômica equivalente ${ }^{5}$ e que a Alemanha alcançou um novo patamar como o

\footnotetext{
${ }^{5}$ Em termos nominais, em 2015, o PIB alemão foi de 3,03 trilhões de euros, seguido pelo britânico (2,57 trilhões) e pelo francês (2,18 trilhões) Ver: http://europa.eu/about-eu/countries/index_pt.htm
} 
Estado mais rico e mais populoso ${ }^{6}$ da União Europeia e que exerce um papel político preponderante ${ }^{7}$. Segundo Raquel Patrício (2006), para que o eixo franco-alemão continue a funcionar como motor central da integração europeia, é necessário que a Alemanha esteja disposta a sacrificar alguns dos atributos de grande potência e que a União Europeia seja capaz de se adaptar e de conviver com uma Alemanha fortificada.

\section{O eixo argentino-brasileiro e a integração mercosulina}

À semelhança do caso franco-alemão, a relação entre Brasil e Argentina foi permeada de tensões e de rivalidades desde 1870, com o fim da Guerra do Paraguai e a consolidação do Estado argentino, que trouxe um rival para o Brasil na Bacia do Prata, até 1979-1980, quando foram assinados o Acordo Tripartite e o Acordo de Cooperação Nuclear, dando início à cooperação bilateral que se estenderia ao âmbito sul-americano (PATRÍCIO, 2006). A partir de 1991, os países tornaram-se o motor do processo de integração regional, com a criação do Mercosul.

Em 1960, a criação da ALALC simbolizou uma das primeiras tentativas integracionistas na América do Sul; no entanto, o bloco não conseguiu consolidar-se efetivamente como uma zona de livre comércio e foi substituído, em 1980, pela ALADI. Além dessas associações, o Tratado da Bacia do Prata e o Acordo de Cartagena, também conhecido como Pacto Andino, ambos firmados em 1969, bem como o Sistema Econômico Latino Americano (SELA), criado em 1975, representaram iniciativas no sentindo da integração regional (PATRÍCIO, 2006).

Apesar destas tentativas anteriores, foi, de fato, na passagem dos anos 70 para os 80 , que as relações entre Argentina e Brasil assumiram um novo patamar, que impulsionou, de maneira decisiva, a integração na América do Sul. Enquanto a assinatura do Acordo Tripartite, em 1979, colocou fim ao contencioso das águas ao contemplar ambas as propostas de Itaipu

\footnotetext{
${ }^{6}$ Em 2015, a população aproximada da Alemanha era de 81 milhões de habitantes. Para este mesmo ano a França registrou 66,4 milhões e o Reino Unido 64,8 milhões. Ver: http://europa.eu/about-eu/countries/index_pt.htm

${ }^{7}$ Com a progressiva liquidação dos maiores passivos de política externa do país que remetiam ao período do pós-Segunda Guerra Mundial e da divisão em duas Alemanhas, a principal pretensão política alemã é um assento permanente no Conselho de Segurança da ONU. A Alemanha é o terceiro maior contribuinte para o orçamento da organização, integrou o Conselho como membro não permanente por três mandatos desde sua reunificação, e seu pleito recebe apoio da França, do Reino Unido e da Rússia. Desde 2004, tem ampliado sua campanha, o que coincide com a formação do G4, ao lado de Brasil, Índia e Japão. Ademais, o papel político preponderante também se reflete em termos de representatividade, o que está diretamente associado ao tamanho da população. A Alemanha conta com 29 votos no Conselho da União Europeia (mesmo número de França, Reino Unido e Itália) e com 96 eurodeputados (bem à frente do segundo país com mais parlamentares, a França, que tem 74). Em termos econômicos, é importante lembrar que o euro se beneficiou do status do marco alemão como segunda divisa de reserva internacional mais utilizada, atrás apenas do dólar americano, e que o Banco Central Alemão serviu de modelo para o Banco Central Europeu, que está sediado em Frankfurt, mesma cidade-sede do Banco Central Alemão.
} 
e Corpus $^{8}$, o Acordo de Cooperação Nuclear, em 1980, encerrou a corrida por artefatos nucleares estruturando uma dinâmica de cooperação argentino-brasileira nesta área.

De acordo com Alessandro Candeas (2005), o relacionamento Brasil-Argentina se transforma, ao longo da história, de conjuntural para estrutural, isto é, deixa de se restringir apenas a questões pontuais, principalmente na área econômica, e se torna central na elaboração das estratégias de política externa de ambos os países. Candeas (2005) divide o relacionamento Brasil-Argentina em cinco momentos: 1) instabilidade estrutural com predomínio da rivalidade (1810-1898); 2) instabilidade conjuntural e busca de cooperação (1898-1961); 3) instabilidade conjuntural com rivalidade (1962-1979); 4) construção da estabilidade estrutural pela cooperação (1979-1987); 5) e pela integração (1988). Segundo o autor:

(...) em 1979, a relação Brasil-Argentina dá um salto qualitativo extraordinário, elevando de forma irreversível o patamar dos laços bilaterais. Ainda durante os regimes militares, os entendimentos alcançados em torno dos pontos de maior confrontação - Itaipu e programas nucleares - fortalecem a confiança e modificam para sempre a natureza dos laços entre os dois países: torna-se obsoleta a hipótese de conflito e se inaugura a fase de construção da estabilidade estrutural no relacionamento entre os dois países pela via da cooperação (CANDEAS, 2005, pg. 23).

É interessante notar que a parceria e a cooperação em setores estratégicos, similarmente ao caso franco-alemão, proporcionaram a mudança no relacionamento bilateral entre Brasil e Argentina e a construção de uma cooperação regional que culminou com o processo de integração. Ademais, a aproximação entre os países por conta do conflito nas Malvinas, em 1982, a despeito da neutralidade assumida pelo Brasil naquela guerra, e o apoio inequívoco brasileiro à revindicação argentina fortaleceu a confiança recíproca. O processo de redemocratização em ambos os países, com o fim das ditaduras militares, também contribuiu para a emergência de uma cultura de amizade e integração (CANDEAS, 2005).

Mais uma vez, assim como no caso da França e da Alemanha, os líderes nacionais desempenharam papel de destaque na consolidação desse novo padrão de relacionamento entre os Estados. Os governos de José Sarney e Raúl Alfonsín protagonizaram a mudança de orientação, trazendo a perspectiva da integração como forma de solucionar os problemas comuns. Em 1986, Sarney e Alfonsín assinaram a Ata para Integração Argentino-Brasileira com seus 12 protocolos de cooperação e criaram a Comissão de Execução do Programa de Integração Binacional, o qual, posteriormente, com um enfoque gradual e flexível, foi estendido aos outros países do Cone Sul, fundando as bases para o processo de integração.

\footnotetext{
${ }^{8}$ A rivalidade nesta questão relacionava-se à suposta incompatibilidade dos projetos brasileiro, Itaipu, e argentino, Corpus. O Acordo Tripartite, que trata do aproveitamento dos recursos hídricos do Rio Paraná até a foz do Rio da Prata, pôs fim à crise Itaipu-Corpus.
} 
Dois anos depois, os presidentes assinaram o Tratado de Integração, Cooperação e Desenvolvimento, que assentou as relações em eixo e estabeleceu o prazo de dez anos para conformação de um espaço econômico comum, o que foi modificado, posteriormente, pela Ata de Buenos Aires, em 1990, que reduziu o prazo para cinco anos. Finalmente, em 1991, juntamente com Uruguai e Paraguai, Brasil e Argentina assinaram o tratado constitutivo do Mercosul conformando um espaço de integração regional na América do Sul. Com o Protocolo de Ouro Preto, em 1994, foi consolidada a estrutura institucional para o bloco regional, que passou a ter personalidade jurídica.

No âmbito nuclear, a parceria argentino-brasileira consolidou-se a partir do início da década de 1990, com a criação da Associação Brasileiro-Argentina de Contabilidade e Controle de Materiais Nucleares (ABACC) e com a assinatura do Acordo Quadripartite entre Brasil, Argentina, ABACC e a Agência Internacional de Energia Atômica (AIEA), ambos em 1991. Em 1994, o Brasil promulgouo Acordo de Tlatelolco sobre a proibição de armas nucleares na América Latina e Caribe, após depositar a Declaração de Dispensa prevista no segundo parágrafo do art. 28 do documento, e, em 1997, Brasil e Argentina estabeleceram uma aliança estratégica, que se materializou, entre outros, por meio do estabelecimento de um mecanismo permanente de consulta e coordenação bilateral nas temáticas de defesa e segurança internacional ${ }^{9}$. Estas iniciativas auxiliaram na conformação de uma zona de paz livre ameaças nucleares na América do Sul e promoveram a construção de confiança mútua e coordenação política necessárias para o desenvolvimento da integração regional.

De fato, a aproximação e a efetiva cooperação entre Argentina e Brasil divergia do padrão de relacionamento existente até então. Candeas (2005, pg.24) ressalta essa diferença ao comparar as opções que a Argentina adotou em relação ao Brasil e a outros países no mesmo período: "É muito significativo o fato de que a Argentina - que na época tinha como hipóteses de conflito Brasil, Chile e Reino Unido - tenha decidido aprimorar seus laços com o Brasil, na contramão das políticas adotadas com os dois últimos". Isto reforça a ideia do path dependence de opção por um caminho, em um momento crítico, diferente das condições antecedentes.

No final da década de 1990 e no início dos anos 2000, as relações bilaterais foram afetadas pela desvalorização do Real e por problemas internos na Argentina de deterioração social e econômica. Ademais, o contexto internacional após a liberalização comercial dificultou as primeiras fases do processo de integração sul-americano, que ficou relativamente marginalizado devido às crises internas dos países-membros e à reorientação de suas políticas externas, direcionando-as para o relacionamento mais próximo com os Estados Unidos.

É importante ressaltar que, diferentemente do eixo franco-alemão, que já almejava a reconstrução de uma Europa unida, no caso argentino-brasileiro, a conjuntura regional e

\footnotetext{
${ }^{9}$ Ver: http://dai-mre.serpro.gov.br/atos-internacionais/bilaterais/1997/b_34_2011-09-01-14-09-52/
} 
o processo de globalização, no início dos anos 1990, foram os grandes catalisadores da institucionalização de um processo regional, o qual não era o objetivo inicial dos respectivos governos. De modo a superar as dificuldades impostas pelo Estado norma ${ }^{10} \mathrm{com}$ a liberalização econômica mundial, Brasil e Argentina voltaram-se um para o outro no sentido de edificar um espaço regional integrado no continente sul-americano.

Em meados de 2012, a Venezuela adentrou ao Mercosul ${ }^{11}$ e, em dezembro desse mesmo ano, a Bolívia deu início ao seu processo de adesão como Estado Parte. Além dos países-membros, são Estados Associados do Mercosul o Chile, o Peru, a Colômbia e o Equador, além de Guiana e Suriname, que adquiriram esse status em julho de $2013^{12}$. Em suma, todos os países da América do Sul estão vinculados ao Mercosul, seja como Estado Parte, seja como Associado, o que evidencia a extensão desse processo de integração regional. Brasil e Argentina, por serem os Estados de maior relevância político-econômica, continuam liderando este processo, ainda que a incorporação da Venezuela estabeleça uma nova distribuição do poder regional.

\section{O método do path dependence e os processos de integração}

De modo a aplicar o método do path dependence aos casos de integração regional, é importante, em primeiro lugar, identificar as condições antecedentes e a conjuntura crítica que propiciaram a escolha de uma opção que, naquele momento, levou à formação de estruturas institucionais autorreprodutivas. No caso da União Europeia, o padrão de comportamento vigente entre França e Alemanha era de rivalidade e de disputa territorial, o que define as condições antecedentes. A Segunda Guerra Mundial simbolizou a conjuntura crítica a partir da qual ocorreu uma mudança no caminho até então seguido por França e Alemanha. Ambos os países optaram pela cooperação, em detrimento da rivalidade, e estabeleceram uma aproximação por meio da criação da CECA, que, por sua vez, se desdobrou em outras estruturas institucionais cooperativas que auxiliaram no processo de consolidação da integração europeia.

No caso do Mercosul, similarmente, as condições antecedentes caracterizavam-se por relações de tensão e de rivalidade entre Argentina e Brasil. O contencioso das águas na Bacia do Prata e a desconfiança mútua no âmbito do desenvolvimento nuclear definiram

\footnotetext{
${ }^{10}$ Segundo Amado Cervo, o Estado normal ou neoliberal, "grande invenção da inteligência política latino-americana da década de 1990", caracteriza-se por uma ruptura em relação ao paradigma do Estado desenvolvimentista. Os governantes no poder naquele momento, como Pinochet, no Chile, Menem, na Argentina, Fujimori, no Peru, e Collor de Melo, no Brasil, adotaram políticas neoliberais e monetaristas, via tratamento de choque, que se contrapunham à estratégia de indução de desenvolvimento por meio de políticas de Estado. Competia ao Estado a função de promover a estabilidade econômica e cabia ao mercado a promoção do desenvolvimento. Ver: http://www.scielo.br/scielo.php?script=sci_arttext\&pid=S0034-73292003000200001

${ }^{11}$ Em junho de 2012, com a suspensão do Paraguai do Mercosul, único país-membro que ainda não havia aprovado o protocolo de adesão venezuelano, a Venezuela foi incorporada ao bloco.

${ }^{12}$ Ver: http://www.itamaraty.gov.br/pt-BR/politica-externa/integracao-regional/686-mercosul
} 
uma conjuntura crítica na qual os países escolheram a alternativa da cooperação ao invés do padrão competitivo das relações até então. A assinatura do Acordo Tripartite e do Acordo para Cooperação Nuclear significou o primeiro passo na construção da confiança mútua para o estabelecimento de estruturas institucionais regionais que culminaram na integração do Cone Sul.

Não é objetivo deste trabalho descrever mais detalhadamente a persistência institucional e as sequências reativas, uma vez que a literatura já produziu diversos trabalhos sobre as temáticas ${ }^{13}$, apenas reiterar que ambos os processos de integração passaram por momentos de avanços e de estagnação que se refletiram em reações e em contrarreações dos países-membros, delineando as novas estruturas institucionais da integração. $\mathrm{O}$ importante nesta análise é compreender que, diante de determinadas conjunturas críticas, os atores-chave, no caso os eixos franco-alemão e argentino-brasileiro, fizeram escolhas que modificaram o padrão de comportamento predominante até aquele momento, fomentando a criação de novas estruturas institucionais de cooperação, as quais resultaram nas respectivas integrações europeia e mercosulina. Em ambos os casos, aplica-se a ideia do path dependence de que uma vez escolhido este caminho, torna-se muito mais difícil para os atores retornar ao patamar anterior.

As figuras abaixo exemplificam de maneira simplificada a metodologia do path dependence aplicada aos casos de integração regional.

Figura 2: Eixo franco-alemão e a integração europeia

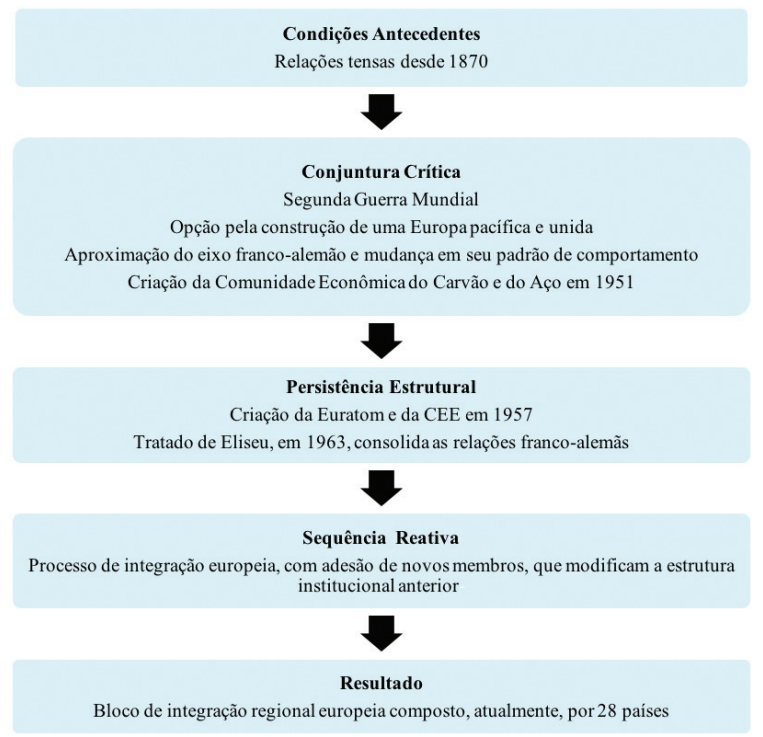

Fonte: elaboração da autora

${ }^{13}$ Ver: PFETSCH, Frank. A União Europeia História, Instituições, Processos. Brasília: Editora UnB, 2002; LESSA, Antônio Carlos. A Construção da Europa: a última utopia das relações internacionais. Brasília: Instituto Brasileiro de Relações Internacionais, 2003; MARIANO, Marcelo Passini. $A$ Estrutura Institucional do Mercosul. Editora Aduaneiras, 2000; BAPTISTA, Luiz Olavo. O Mercosul: suas instituições e ordenamento jurídico. São Paulo: LTr, 1998. 
Figura 3: Eixo argentino-brasileiro e a integração mercosulina

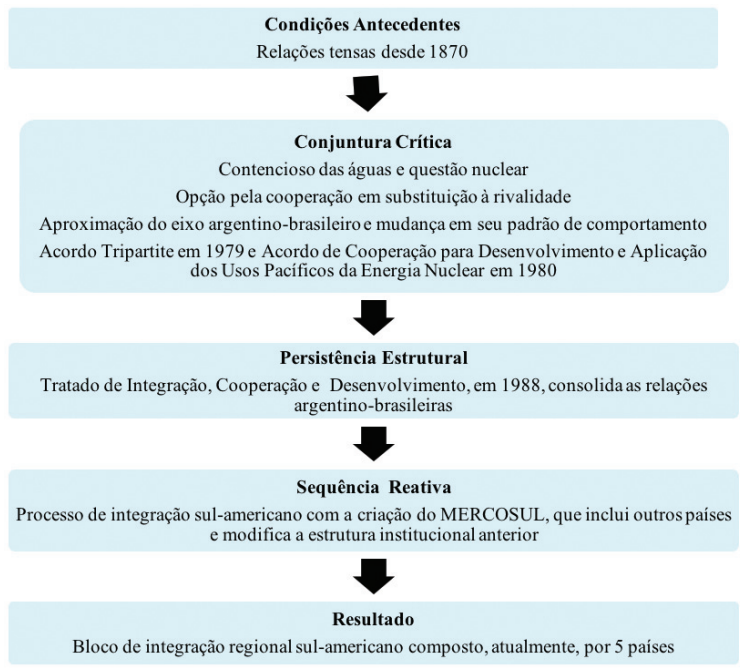

Fonte: elaboração da autora

\section{A inércia institucional nos processos de integração regional}

De acordo com a metodologia do path dependence, as escolhas dos atores-chaves em uma determinada conjuntura crítica levam à formação de instituições com propriedades autorreprodutivas ao longo do tempo (MAHONEY, 2001). Nesse sentido, uma vez que determinados padrões estruturais, no caso a aproximação entre os eixos franco-alemão e argentino-brasileiro, respectivamente, são estabelecidos, criam-se mecanismos relativamente autônomos de reprodução institucional. Esse processo de adensamento das instituições é, muitas vezes, permeado pela excessiva criação de novos órgãos, pelo aumento da burocratização e pela sobreposição de grupos e comissões. A reprodução institucional ineficaz é denominada inércia institucional. Observa-se, especialmente na integração sul-americana, que o insucesso de um determinado órgão é rapidamente ocultado pela criação de novos organismos em temas correlatos que são anunciados como grandes conquistas e avanços na cooperação interestatal ainda que efetivamente não se diferenciem das instituições já existentes.

O path dependence pode auxiliar na explicação das dificuldades de mudança institucional, pois, uma vez instauradas, as instituições podem limitar as mudanças de políticas e condicionar as escolhas futuras dos atores. Conforme explicitado anteriormente, o path dependence fundamenta-se no conceito de retornos crescentes da teoria econômica, ou seja, a ideia de que os benefícios de se manter na mesma trilha aumentam ao passo que o custo dos caminhos alternativos também. Segundo Thelen (1999 apud SEHRING, 2009), o path dependence torna-se efetivo por meio dos mecanismos de feedback, que geram efeitos funcionais e distribucionais. Por um lado, os efeitos funcionais referem-se ao fato de que, quando as instituições se estabelecem, os atores adaptam suas estratégias a estas, 
de forma que não só refletem, mas também reiteram a lógica do sistema; por outro lado, os efeitos distribucionais relacionam-se com as assimetrias de poder e de interesses reforçadas pelas instituições existentes e que marginalizam as demais alternativas de arranjos institucionais. Sendo assim, "the reason for the genesis and persistence of institutions is hence not only that they perform a certain function, but also that they serve certain interests. Institutional continuity is not something static, but a dynamic process of reproduction and adaptation" (SEHRING, 2009, pg. 65).

O resultado desses efeitos funcionais e distribucionais é a dificuldade de realizar reformas mediante a desestruturação das instituições existentes, isto é, voltar ao ponto inicial anterior a conjuntura crítica, onde não havia os padrões institucionais que resultaram da escolha feita naquele momento-chave. Desta maneira, estas instituições não são substituídas, mas, sim, complementadas por novos mecanismos institucionais, que vão acumulando-se e sobrepondo-se como que em um processo de bricolage. Para Sehring (2009), o termo institutional bricolage refere-se a um processo parcialmente proposital e parcialmente não intencional de combinação e de transformação de elementos institucionais que resultam em um novo tipo de instituição. Segundo o autor, "institutional bricolage therefore offers an approach to institutional change that is situated between path dependency and the development of new, alternative paths, which are never completely new but a recombination of existing institutional elements and new concepts" (SEHRING, 2009, pg.66).

Aplicando estas ideias à União Europeia e ao Mercosul, pode-se depreender que da aproximação, respectivamente, dos eixos França-Alemanha e Argentina-Brasil, em determinadas conjunturas críticas, estabeleceu-se um novo padrão de relacionamento, que contribuiu para a estruturação institucional que, posteriormente, resultou nos processos de integração regional. Após o estabelecimento dos pilares da cooperação bilateral, desdobrou-se um processo de reprodução institucional, delimitando a nova estrutura desses relacionamentos interestatais, que se estendeu aos países vizinhos. Os demais tratados e acordos que derivaram desse processo procuraram responder, em certa medida, às novas demandas sem alterar fundamentalmente as bases institucionais existentes. Assim sendo, ressalta-se a dificuldade de promover reformas estruturais em ambos os blocos.

No caso da União Europeia, algumas análises indicam que diante da situação de inércia institucional a que o bloco chegou atualmente, não seria mais possível avançar simultaneamente tanto em termos de alargamento quanto de aprofundamento. Há quem diga que continuar as negociações para um novo alargamento é uma sentença de morte, pois os custos seriam muito grandes para a manutenção do atual nível de cooperação interna no bloco (STEUNENBERG, 2002). Embora criticada, a inércia institucional também revela seus benefícios, como a preservação dos padrões de interação dentro da União Europeia, apesar do aumento do número de membros e dos interesses divergentes (BEST; CHRISTIANSEN; SETTEMBRI, 2008). Desta forma, o sistema continua a operar, relativamente, sem rupturas, ainda que reformas extensas sejam mais improváveis de ocorrerem. 
Uma das dificuldades dos processos de integração é definir quais incumbências cabem ao bloco regional como uma entidade supranacional e quais pertencem aos Estados membros em suas atuações nacionais. O Tratado de Lisboa, assinado em 2007, delimita as competências da União Europeia e rege-se pelo princípio da atribuição, ou seja, a União deve atuar dentro dos limites que lhe forem atribuídos pelos Estados membros para alcançar os objetivos definidos nos tratados. O Tratado de Lisboa esclarece a repartição de competências entre a União Europeia e os países-membros, as quais estão divididas em três categorias: 1) exclusivas, que se referem aos domínios nos quais apenas a União Europeia pode legislar e adotar atos vinculativos, cabendo aos países-membros somente a aplicação da lei; 2) partilhadas, que se relacionam com as áreas nas quais os Estados membros estão habilitados a legislar quando a União Europeia não o tenha feito; 3) de apoio, que se vinculam aos setores nos quais a União Europeia pode intervir apenas para apoiar, coordenar ou complementar as políticas dos países-membros, sem exigir a harmonização legislativa.

De acordo com o tratado, a União Europeia dispõe de competência exclusiva nas seguintes áreas: união aduaneira; estabelecimento das regras de concorrência necessárias ao funcionamento do mercado interno; política monetária para os países da área do euro; conservação dos recursos biológicos do mar; política comercial comum; e celebração de acordos internacionais em determinadas condições. As competências partilhadas, por sua vez, aplicam-se aos domínios: do mercado interno; da política social; da coesão econômica, social e territorial; da agricultura e da pesca; do ambiente; da defesa dos consumidores; dos transportes; das redes transeuropeias; da energia; do espaço de liberdade, segurança e justiça; dos problemas comuns de segurança em matéria de saúde pública; da investigação, desenvolvimento tecnológico e espaço; e da cooperação para o desenvolvimento e ajuda humanitária. E as competências de apoio foram atribuídas aos setores de: proteção e melhoria da saúde humana; indústria; cultura; turismo; educação, formação profissional, juventude e desporto; proteção civil; e cooperação administrativa ${ }^{14}$.

De fato, o Tratado de Lisboa procurou delimitar melhor as competências no âmbito da integração europeia e reforçou a ideia de que o exercício das mesmas deve ser guiado pelos princípios de proporcionalidade e de subsidiariedade. Enquanto para o primeiro a atuação da União Europeia não deve exceder o necessário para que sejam alcançados os objetivos dos tratados, o segundo entende que, no que se refere às competências não exclusivas, o bloco deve apenas intervir na medida em que os Estados membros não possam alcançar os objetivos individualmente. Embora o tratado procure delimitar a divisão de competências, a falta de clareza e de precisão na definição das áreas de atuação da União Europeia e dos países membros pode gerar alguns conflitos e/ou zonas de penumbra, principalmente no que tange às competências partilhadas. Isto porque, em geral, a União tem a tendência de legislar em domínios que não são exclusivamente de sua competência, e o controle para

\footnotetext{
${ }^{14}$ Ver: http://eur-lex.europa.eu/legal-content/PT/TXT/HTML/?uri=URISERV:ai0020\&from=PT
} 
garantir o princípio de subsidiariedade nem sempre é efetivo, uma vez que não há plena clareza dos critérios para aferir-se a existência de uma situação em que o Estado membro não esteja conseguindo alcançar os objetivos propostos. Ademais, em muitos casos, o cidadão europeu não consegue compreender quem é responsável por determinada política dentro do âmbito da integração regional, o que enfraquece o seu papel de stakeholder no processo de integração e a eficácia dos mecanismos de prestação de contas (“accountability").

No momento, os principais desafios à integração europeia relacionam-se com a crise na Zona Euro e o aumento dos fluxos de migração em virtude das recentes ondas de refugiados chegando ao continente. Soma-se ainda o ressurgimento de movimentos de extrema direita nos países-membros e o aumento do euroceticismo. O referendo britânico sobre uma possível saída da União Europeia, por exemplo, é reflexo da insatisfação do Reino Unido em alcançar seus objetivos dentro da estrutura comunitária. Em fevereiro deste ano, foi negociado um status especial que será concedido ao país caso este decida permanecer no bloco regional. Essa concessão abre espaço para questionamentos sobre o futuro da União Europeia e o adensamento da integração. Diante desses cenários, o bloco europeu enfrenta dificuldades em conciliar os interesses dos 28 Estados membros e promover respostas comunitárias. Ademais, a integração europeia ainda não conseguiu aprofundar-se em temáticas mais sensíveis, como a segurança.

No Mercosul, ainda que com que menos Estados Partes em comparação com a União Europeia, a ineficácia e a inércia institucional são muito maiores. De acordo com Crawley (2004), o problema do Mercosul não é a falta de regras, mas, sim, a existência de normas de baixa qualidade sem foco adequado, que, em alguns casos, não regulam nada efetivamente.

Mercosur has 37 norms on the harmonization of sanitary and phytosanitary standards but they do not really harmonize anything; they amount to little more than a list of measures; the Protocols of Colonia and Montevideo are mutually incompatible; nothing has been achieved in the area of rules on service trade, apart from telecommunications; and (a striking example of institutional inertia) the 1995 inter-regional framework cooperation agreement between Mercosur an EU has never been formally approved by Mercosur $^{15}$ (CRAWLEY, 2004, pg. 8)

Crawley (2004) destaca também que um dos aspectos críticos da integração mercosulina está no estabelecimento de regras que conduzam a um aprofundamento institucional coeso e coerente com os objetivos definidos. Caso contrário, o processo sujeita-se a momentos políticos favoráveis ou não e a circunstâncias nacionais particulares para avançar. Em muitas áreas do Mercosul, a produção de protocolos e de regulações tornou-se dissociada

${ }^{15}$ Após paralisação em 2004, em 2010 foram retomadas as negociações entre Mercosul e União Europeia, mas novas ofertas comerciais só foram trocadas em 2016. 
de instrumentos de implementação em termos de prazos e de mecanismos de cumprimento e de execução.

No que se refere à sobreposição ou à duplicação de grupos e de comissões, é interessante observar que, no Mercosul, existe certo paralelo entre instâncias técnicas e políticas, mas que não estão necessariamente submetidas aos mesmos órgãos. As instâncias técnicas estão vinculadas ao Grupo Mercado Comum $(\mathrm{GMC})^{16}$, que se reúne periodicamente, enquanto as políticas se vinculam ao Conselho Mercado Comum $(\mathrm{CMC})^{17}$, que realiza reuniões semestrais. Em temas como meio ambiente, agricultura, e saúde, a estrutura mercosulina comporta subgrupos de trabalho, no âmbito do GMC, ao mesmo tempo em que prevê reuniões ministeriais, que estão submetidas ao CMC. Em ciência e tecnologia ou em turismo, por sua vez, preveem-se tanto reuniões especializadas no âmbito do GMC como reuniões ministeriais vinculadas ao $\mathrm{CMC}{ }^{18}$

A dissociação entre instâncias também permeia outras áreas do organograma do Mercosul. Essa duplicidade, em muitos casos, transcende a lógica intrainstitucional, uma vez que o tratamento de alguns temas na esfera regional não apenas complementa, mas também se sobrepõe a iniciativas bilaterais. No tratamento da temática de fronteiras, por exemplo, em 2014, foi revogada a decisão mercosulina que criou Grupo Ad Hoc sobre Integração Fronteiriçac ${ }^{19}$. Recentemente, foi criado o Subgrupo de Trabalho no 18, no âmbito do GMC, para discutir integração fronteiriça nas mais diversas frentes específicas, como saúde, educação, trabalho, migração, transporte, infraestrutura e desenvolvimento urbano. Ainda no Mercosul, especificamente no que diz respeito à integração de estados e municípios, a integração fronteiriça é discutida em grupo ad hoc do Foro Consultivo de Municípios, Estados Federados, Províncias e Departamentos do Mercosul (FCCR), também vinculado ao GMC. Adiciona-se a essa multiplicidade de fóruns as comissões bilaterais que os países-membros mantêm, como é o caso da Comissão de Cooperação e Desenvolvimento Fronteiriço, entre Brasil e Argentina.

Outro exemplo de inércia institucional e de sobreposição de instituições pode ser observado no âmbito social da integração regional no Cone Sul. A partir do governo do presidente Luiz Inácio (Lula) da Silva, o Mercosul adensou seu caráter social com a criação da Cúpula Social do Mercosul, em 2006, e do Instituto Social do Mercosul em

\footnotetext{
${ }^{16}$ O Grupo Mercado Comum (GMC) é um órgão decisório executivo do Mercosul, responsável por fixar os programas de trabalho e por negociar acordos com terceiros mediante delegação expressa do Conselho Mercado Comum. O GMC se pronuncia por Resoluções e é composto por quatro membros titulares e quatro membros alternos por país, dentre os quais devem constar necessariamente representantes dos Ministérios das Relações Exteriores, dos Ministérios da Economia (ou equivalentes) e dos Bancos Centrais.

${ }^{17} \mathrm{O}$ Conselho Mercado Comum (CMC) é o órgão supremo do Mercosul, cuja função é a condução política do processo de integração. O CMC é formado pelos Ministros de Relações Exteriores e de Economia dos Estados Parte, que se pronunciam através de Decisões.

${ }^{18} \mathrm{http}: / /$ www.mercosur.int/innovaportal/v/492/2/innova.front/organigrama

${ }^{19}$ A Decisão 24/14 do Conselho do Mercado Comum revogou a Decisão 05/02, do mesmo órgão, que criou o GAHIF.
} 
2007. A Cúpula é um espaço para o diálogo entre os governos e a sociedade civil, que reúne semestralmente representantes governamentais, de parlamentos, centrais sindicais, pastorais sociais, entre outras entidades, para tratar de temas como economia solidária, direitos humanos, gênero, juventude, meio ambiente, saúde e educação com o objetivo de promover a transparência, a difusão de informações e a troca de experiências sobre as políticas sociais desenvolvidas no bloco ${ }^{20}$. Resultado de iniciativa da Reunião de Ministros e Autoridades de Desenvolvimento Social do Mercosul, o Instituto, por sua vez, visa fortalecer a articulação das políticas sociais de modo a contribuir para a superação das assimetrias intrabloco.

Ainda na área social, o Mercosul ampliou a participação da sociedade no processo de integração regional por intermédio de iniciativas como o Foro Consultivo Econômico-Social (FCES) e a Unidade de Participação Social (UPS). Enquanto o FCES representa os setores da economia e da sociedade manifestando-se por meio de recomendações, referentes tanto à questões internas do bloco quanto à relação deste com outros países e organismos internacionais, ao GMC ${ }^{21}$; a UPS, que começou a funcionar em 2013, procura promover e aprofundar o envolvimento de organizações e movimentos sociais da região no bloco, bem como dar apoio às Cúpulas Sociais e financiar a participação social em atividades do Mercosul ${ }^{22}$.

No âmbito interno, o Brasil e a Argentina desenvolveram também instrumentos similares para incluir a sociedade civil, a exemplo do Mercosul Social e Participativo e do Consejo Consultivo de la Sociedad Civil (CCSC), respectivamente. Por um lado, o Mercosul Social e Participativo é um programa brasileiro que reúne tanto entidades da administração pública federal como organizações convidadas da sociedade civil com o intuito de encaminhar propostas e sugestões, a partir das discussões realizadas na sociedade civil, ao CMC e ao GMC; por outro lado, o CCSC é um órgão da chancelaria argentina para promover a participação da sociedade civil nos processos de tomada de decisão em matéria de política exterior e não exclusivamente voltado para o Mercosul, ainda que também atue em prol do fortalecimento da participação da sociedade civil argentina no bloco. Essa duplicidade e heterogeneidade de organismos para tratar de temas correlatos na área social tende a esvaziar os espaços de participação da sociedade civil em função da dificuldade de organizar e centralizar as demandas existentes.

O adensamento normativo e organizacional do Mercosul, em um ambiente de inércia institucional, conforme apresentado, é, ao lado da conjuntura interna peculiar do país, um entrave à plena integração da Venezuela ao bloco. Em vigor desde 2012, o Protocolo de Adesão da República Bolivariana da Venezuela ao Mercosul prevê, em seu artigo $3^{\circ}$, que o

\footnotetext{
${ }^{20}$ Ver: http://www.mercosul.gov.br/o-mercosul-na-vida-do-cidadao/cupula-social-do-mercosul

${ }^{21}$ Ver: http://www.mercosur.int/innovaportal/v/6572/9/innova.front/foro-consultivo-econ\%C3\%B4mico-social-fces

${ }^{22}$ Ver: http://www.mercosur.int/innovaportal/v/5819/9/innova.front/unidade-de-apoio-participac $\% \mathrm{C} 3 \% \mathrm{~A} 30$-social-ups
} 
país “adotará o acervo normativo vigente do Mercosul, de forma gradual, no mais tardar em quatro anos contados a partir da data de entrada em vigência" ${ }^{23}$ do instrumento. $\mathrm{O}$ mesmo período está previsto, no artigo $4^{\circ}$, para a adoção da Nomenclatura Comum do Mercosul (NCM) e a Tarifa Externa Comum (TEC). Para acompanhar o processo, foi criado, pelo artigo 11, o Grupo de trabalho para a negociação do processo de adesão da República Bolivariana da Venezuela (GTVENE), vinculado ao CMC.

Às vésperas do fim do prazo de quatro anos, que se encerra em agosto, carece de incorporação na Venezuela boa parte das normativas do bloco. O país ainda não foi incorporado ao Acordo de Complementação Econômica 18, que reúne os demais países mercosulinos, e o comércio venezuelano com os sócios segue regulado por acordos bilaterais no âmbito da ALADI. A adequação da Venezuela à TEC tampouco está concluída, e o país tem dificuldades para cumprir o cronograma acordado, previsto no Decreto 9.430, do Governo venezuelano, publicado em março de 2013.

O não cumprimento do disposto no Protocolo de Adesão tem suscitado dúvidas sobre a efetiva integração da Venezuela ao Mercosul, principalmente quando o país deve assumir a presidência rotativa do bloco no segundo semestre. Dadas as lacunas legais no acervo jurídico do bloco, muito se discute, atualmente, entre os países-membros a respeito dos efeitos e das possíveis sanções à Venezuela, em caso de que o país não cumpra o prazo de quatro anos para a incorporação das normas mercosulinas. Extensão do prazo para a incorporação normativa, suspensão da Venezuela e extensão do mandato uruguaio à frente da presidência rotativa, assunção da presidência pela Argentina: são todas opções que podem estar sobre a mesa de negociações no momento.

A construção do Mercosul demandou mais de duas décadas de envolvimento e de iniciativas dos quatro membros originais. O prazo de quatro anos para que a Venezuela promova a internalização de todo o acervo, concorrendo com um período de forte instabilidade política interna no país, dificilmente será cumprido. A profusão de normativa interna no Mercosul e seu processo de inércia institucional, mostram-se, portanto, obstáculos ao próprio amadurecimento do bloco, uma vez que têm dificultado a concretização do primeiro alargamento do número de seus membros plenos.

\section{Conclusão}

Este trabalho utilizou o método histórico do path dependence para analisar o início dos processos de integração regional na Europa e na América do Sul. A aproximação entre os eixos franco-alemão e argentino-brasileiro em determinadas conjunturas críticas e a opção destes atores em adotarem um caminho diferente das condições antecedentes priorizando a cooperação em detrimento da rivalidade pavimentaram a estrada para os respectivosprocessos

\footnotetext{
${ }^{23}$ Mercosul. Protocolo de Adesão da República Bolivariana da Venezuela ao Mercosul. Disponível em: http://www.desenvolvimento.gov.br/arquivos/dwnl_1377717219.pdf
} 
de integração regional. A partir destes entendimentos bilaterais, estabeleceram-se mecanismos institucionais que se estenderam a outros países fomentando e consolidando a integração.

De acordo com a lógica do path dependence, uma vez escolhido um caminho, há uma tendência a mover-se cada vez mais na direção selecionada, pois os custos de mudança de trajetória são maiores. Isso explica, em alguma medida, o gradativo aprofundamento de ambos os processos de integração ainda que cada um em seu próprio ritmo e com períodos de estagnação. De fato, até o momento, nem a União Europeia nem o Mercosul tiveram algum retrocesso significativo no processo de integração; todavia, é preciso atentar-se para a inércia institucional, que pode dificultar reformas, as quais permitirão uma eficácia maior dos blocos.

A União Europeia continua sendo o maior exemplo de integração regional tanto em termos políticos como econômicos; todavia, enfrentará constantes desafios para superar as divergências de um bloco regional altamente heterogêneo no aprofundamento e alargamento da integração e na promoção de soluções comunitárias. O Mercosul, por sua vez, deve superar as dificuldades em avançar na eliminação dos entraves econômicos ainda existentes e na coordenação política. A falta de coesão entre os países-membros e entre suas respectivas políticas internas e externas tem sido um contínuo obstáculo a um maior aprofundamento institucional.

Em síntese, ambos os blocos regionais devem considerar os efeitos da inércia institucional se pretendem continuar na trilha para um adensamento cada vez maior da integração. A multiplicidade de organismos e de normativas, muitas vezes ineficazes e duplicadas, cria empecilhos para que novos membros se adaptem a essa estrutura institucional. Enquanto na União Europeia a entrada de novos Estados pode impossibilitar o aprofundamento do atual nível de integração, o Mercosul ainda não conseguiu regularizar seu primeiro alargamento, com a adesão plena da Venezuela. Ademais, a inércia impede reformas substanciais que modifiquem a estrutura organizacional e, desta forma, tende a manter mecanismos que não se adéquam corretamente às necessidades e aos objetivos do bloco. De modo a evitar o esgotamento dos processos de integração regional, é fundamental que ambos os blocos conciliem seu interesse por novos alargamentos e aprofundamentos com a importância de racionalizar suas estruturas e seus métodos de trabalho, eliminando duplicações desnecessárias, simplificando seu desenho institucional e contendo os efeitos danosos da inércia que se estabeleceu.

\section{Referências bibliográficas}

BEST, Edward; CHRISTIANSEN, Thomas; SETTEMBRI, Pierpaolo (Ed.) The Institutions of the Enlarged European Union: continuity and Change. Edward Elgar: Cheltenham, 2008.

BRUTER, Michael. Citizens of Europe? The emergence of a Mass European Identity. Palgrave Macmillan: New York, 2005. 
CANDEAS, Alessandro Warley. Relações Brasil-Argentina: uma análise dos avanços e recuos. Revista Brasileira de Política Internacional, 48 (1), 2005, pp. 178-213.

CHURCHILL, Wiston. Speech at the University of Zurich on September 19, 1946. Disponivel em: http://www.cfr.org/europe/churchills-united-states-europe-speech-zurich/ p32536 Acesso em: 17/05/2016.

COUTINHO, Marcelo; HOFFMAN, Andrea Ribeiro; KFURI, Regina. Raio X da Integração Regional. Estudos e cenários, Rio de Janeiro: Observatório Político Sul-Americano/ IUPERJ/ UCAM, 2007.

CRAWLEY, Andrew. MERCOSUR: In search of a new agenda. Rapporteur's Report. Inter-American Development Bank, 2004.

EUROPEAN COMMISSION. One currency for one Europe: the road to Euro. Luxembourg: Publications Office of the European Union, 2015.

FERNANDES, Antônio Sérgio Araújo. Path Dependency e os Estudos Histórico Comparados. BIB, São Paulo, n.53, 2002, pp. 79-102.

MAHONEY, James. Path Dependence in Historical Sociology. Theory and Society 29:4 (August 2000), pp. 507-548.

MAHONEY, James. Path-Dependent Explanations of Regime Change: Central America in Comparative Perspective. Studies in Comparative International Development, Spring 2002, Vol. 36, No. 1, pp. 111-141.

MARIANO, Karina Lilia Pasquariello MARIANO, Marcelo Pasini. As teorias de integração regional e os Estados subnacionais. Impulso (Piracicaba), Piracicaba, v. 13, n.31, p. 47-69, 2002.

MITRANY, David. A paz por meio da cooperação e da integração. In: BRAILLARD, Philippe. Teoria das Relações Internacionais. Lisboa: Fundação Calouste Gulbenkian, 1990.

NORTH, Douglass C. Institutions. Journal of Economic Perspectives, vol. 5, n. 1, Winter 1991, p. 97-112.

PATRÍCIO, Raquel. As relações em eixo - novo paradigma da teoria das relações internacionais? Revista Brasileira de Política Internacional, 49 (2), 2006, pg. 5-24.

PINTO, Messias de Sá. A área de livre comércio das Américas e os interesses da União Europeia na América Latina. Tese de doutoramento. Universidade do Minho, Braga, 2004.

RAMOS, Leonardo; MARQUES, Sylvia Ferreira; JESUS, Diego Santos Vieira. A União Europeia e os estudos de integração regional. Belo Horizonte: Del Rey, 2009.

SAURUGER, Sabine. Théories et concepts de l'integration européenne. Paris: Presses de Sciences Po, 2009.

SCHUMAN, Robert. Declaration on May 9, 1950. Disponível em: http:/europa.eu/about-eu/basic-information/symbols/europe-day/schuman-declaration/index_en.htm Acesso em: $17 / 05 / 2016$ 
SEHRING. Jenniver. Path dependencies and Institutional Bricolage in Post-Soviet Water Governance. Water Alternatives 2(1), 2009, p. 61-81.

STEUNENBERG, Bernard (Ed). Widening the European Union: The politics of institutional change and reform.Routledge: London and New York, 2002.

TORRES, Francisco; MAIOR, Paulo Vila. A contribuição da teoria das relações internacionais para a explicação do processo de integração monetária europeia. Relações Internacionais, no. 39 Lisboa, Set. 2013.

Artigo Recebido a 26 de abril de 2016 | Aceite a 06 de junho de 2016 